\title{
Physico-chemical properties of different formulations of pequi pulp with milk
}

\author{
Maria Suiane de Moraes*(D) , Janaina Almeida Dantas Esmero ${ }^{(\mathbb{D}}$, \\ Rossana Maria Feitosa de Figueirêdo ${ }^{(\mathbb{D}}$, Alexandre José de Melo Queiroz ${ }^{(\mathbb{D}}$ \\ Federal University of Campina Grande, Campina Grande, Brazi \\ *Corresponding author, e-mail: suiane-2009@hotmail.com
}

\begin{abstract}
The objective of this work was to perform the physical-chemical characterization of different formulations of the pequi pulp with the addition of different concentrations of whole milk, in order to identify promising products for commercial use. Three formulations of pequi pulp with whole milk were prepared: PL 1-90\% pequi pulp and $10 \%$ milk, PL2 - 70\% pequi pulp and 30\% milk, PL3 - 50\% pequi pulp and 50\% milk. The formulations were evaluated for physical and physical-chemical parameters of color, water activity, water content, ash, total soluble solids (SST), $\mathrm{pH}$, total titratable acidity (ATT), SST/ATT ratio, ascorbic acid, proteins, lipids, total, reducing and non-reducing sugars. The data obtained were subjected to analysis of variance (ANOVA) and comparison between means by the Tukey test at $5 \%$ probability. Among the three tested formulations, the best results were obtained for PL3, where it presented lower total titratable acidity, water activity, red intensity, yellow intensity and chromaticity, however, higher content of total soluble solids, ratio SST/ATT, ash, lipids, sugars (total, dimmer and non-dimmer), luminosity and tint angle. The inclusion of milk in the pequi pulp changed the physical and physical-chemical characteristics of the pulp, and it can be an alternative to add nutritional value to the fruit and consequently a promising product for the market.
\end{abstract}

Keywords: Caryocar coriaceum Wittm, fruit, new products

\section{Introduction}

Pequi (Caryocar Spp.) is a fruit native to the Cerrado region of Brazil that has a high potential for commercialization. It stands out for its economic potential, since it has been used in preparations and by the food industry due to its nutritional value, bioactive and technological properties (Lima et al., 2017; Pinto et al., 2016).

Among the species of the genus Caryocar, the following are predominant in Brazil: C. brasiliense, C. villosum, C. coriaceum, C. cuneatum e C. glabrum (Prance \& Silva, 2006). The species Caryocar coriaceum Wittm is found in the northernmost part of the northeast region, playing an important socio economic role (Batista et al., 2010; Saraiva et al., 2010).

The pequi pulp is eatable after cooking and it is rich in vitamins, lipids and proteins. The high crude fat content of pequi is approximately $65.0 \%$ in dry matter.
The nutritional value of the fruit is determined by the lipid fraction where the main fatty acids are oleic acid (54.0\%) and palmitic acid (39.0\%) (Maia et al., 2008). In addition, pequi contains natural antioxidants, such as phenolic compounds and carotenoids (Ribeiro et al., 2014).

There are several studies that guide the use of pequi in different forms of preparations, encouraging the consumption of this fruit and contributing to its exploitation in technological processes in the food industry (Santos et al., 2016; Souza et al., 2017; Carvalho et al., 2017; Leão et al., 2017; Lima et al., 2017). However, so far, to the best of our knowledge, no research has investigated the physical and physical-chemical characterization of formulations using pequi associated with whole milk. Particularly, considering the range of possibilities of using this fruit, the incorporation of the pequi pulp into whole milk can bring benefits to the consumer by its application in dairy products and/or other forms of preparations, 
adding nutritional value, color, aroma and flavor to new products.

Given this context, this article contributes to the field by presenting new results on the physical and physical-chemical characterization of different formulations of pequi pulp with the addition of different concentrations of whole milk (10,30 and 50\%), in order to identify promising products for commercial use.

\section{Material and Methods}

The pequi fruits (Caryocar coriaceum Wittm) were collected in Chapada do Araripe, located in the south of the state of Ceará, in the mature stage of maturation, stored in polypropylene boxes and transported to the laboratory for further processing.

Upon arrival at the laboratory facilities, the fruits were washed in running water to remove dirt and sanitized in chlorinated solution (100 ppm of active chlorine) for 15 min and rinsed under running water. Subsequently, the pequis were cut to separate the external mesocarp from the internal mesocarp, which was washed with drinking water. For the pulp processing, it was necessary to cook the internal mesocarp at a temperature of $100^{\circ} \mathrm{C}$ for 30 min; then, they were cooled, drained and pulped with the aid of a semi-industrial stainless steel peeler (Max Machine brand). The pulp was packed in polyethylene bags and stored in a freezer $\left(-20^{\circ} \mathrm{C}\right)$ until the time of experimental analysis.

To prepare the formulations, the whole pulp of the fruits was thawed to room temperature and added with commercial whole milk (packaged in a tetra pack) in different concentrations (10,30 and 50\%), the mixes being homogenized in a domestic blender at full speed for 1 minute. The formulations elaborated were: PL1-90\% pequi pulp and $10 \%$ milk, PL2 - 70\% pequi pulp and $30 \%$ milk, PL3 - 50\% pequi pulp and 50\% milk. The formulations developed were evaluated in triplicate. Color analysis was performed by direct reading using the Miniscan HunterLab XE Plus spectrophotometer, model 4500 L, with a Cielab color system. The parameters determined were: $L^{*}$, which represents the luminosity, that is, the transition from black (0) to white (100); a* representing the transition from green $\left(-a^{*}\right)$ to red $\left(+a^{*}\right)$; $b^{*}$ the transition from the intensity of the blue color (-b*) to the yellow color (+ $\left.b^{*}\right)$; from these values, the chroma values $\left(c^{*}\right)$ and the pitch angle values ( $h^{\circ}$ angle) were calculated. The water activity was performed using the Aqualab equipment model 3TE (Decagon Devices, Inc.).

The following physical-chemical parameters were analyzed: $\mathrm{pH}$ in a digital potentiometer, water content through direct drying in a vacuum oven $\left(70^{\circ} \mathrm{C}\right)$; ash by muffle incineration at $550^{\circ} \mathrm{C}$; total acidity titratable by titration with $0.1 \mathrm{~N} \mathrm{NaOH}$; total soluble solids ( ${ }^{\circ}$ Brix) by direct reading on a digital refractometer; protein content quantified according to the Kjeldahl method, where the total nitrogen content is determined and the total protein content is calculated by multiplying the nitrogen content by a factor of 6.25; total and reducing sugars were determined by the Fehling method by hot titration, and non-reducing sugars obtained by the difference between total and reducing sugars. All studies were performed according to the analytical procedures of the Adolfo Lutz Institute (Brasil, 2008). The SST/ATT ratio was obtained by the quotient between total soluble solids and total titratable acidity. The lipid content was determined by the methodology of Bligh \& Dyer (1959) with chloroform, methanol and water. The ascorbic acid content was determined by titration with 2,6 dichlorophenolindophenol sodium (DCFI) until obtaining the light pink color, permanent using oxalic acid (Benassi \& Antunes, 1988) as an extracting solution, following the procedure AOAC (2009).

The experiment was performed in a completely random design, with three replications. The data were submitted to analysis of variance (ANOVA) and, according to the significance of the F test, the Tukey test was applied at $5 \%$ probability, using the computer program ASSISTAT, version 7.7 Beta (Silva \& Azevedo, 2016).

\section{Results and Discussion}

Table 1 shows the average values of the physicochemical characterization of pequi pulp formulations with milk.

The pequi fruit differs from most tropical fruits in that it has a $\mathrm{pH}$ that classifies it as a low acid food $(\mathrm{pH}>$ 4.5) (Oliveira \& Scariot, 2010). In the three formulations, the $\mathrm{pH}$ values were higher than 4.5 , which can contribute to microbial growth. It was observed that the increase in the concentration of whole milk influenced the $\mathrm{pH}$ increase and, consequently, lower values for the total titratable acidity, reaching values close to neutrality. The total soluble solids increased as the milk concentration was increased in the formulations, with average values ranging from 6.00 to 10.00 ( ${ }^{\circ}$ Brix). The SST/ATT ratio of the formulations varied from 2.34 to 5.03 , showing a statistical difference among them. However, it is noted that the highest value is in the formulation with equal proportions of pequi pulp and milk (PL3). The ratio directly influences the flavor of the product, which may vary according to 
Table 1. Average values of the physical-chemical parameters of the formulations of pequi pulp with milk.

\begin{tabular}{|c|c|c|c|}
\hline \multirow{2}{*}{ Parameters analyzed } & \multicolumn{3}{|c|}{ Formulations } \\
\hline & PL1 & PL2 & PL3 \\
\hline $\mathrm{pH}$ & $4.74 \pm 0.00$ & $5.50 \pm 0.01$ & $6.00 \pm 0.01$ \\
\hline Total titratable acidity (\% citric acid) & $2.56 \pm 0.01^{a}$ & $2.19 \pm 0.01^{b}$ & $1.99 \pm 0.01^{c}$ \\
\hline Total soluble solids ( ${ }^{\circ}$ Brix) & $6.00 \pm 0.00^{c}$ & $9.00 \pm 0.00^{\mathrm{b}}$ & $10.00 \pm 0.00^{a}$ \\
\hline Ratio SST/ATT & $2.34 \pm 0.01^{c}$ & $4.12 \pm 0.03^{b}$ & $5.03 \pm 0.05^{a}$ \\
\hline Ashes (\%) & $0.23 \pm 0.00^{c}$ & $0.40 \pm 0.01^{b}$ & $0.48 \pm 0.00^{a}$ \\
\hline Water content (\%) & $82.94 \pm 0.31^{c}$ & $84.70 \pm 0.06^{a}$ & $83.82 \pm 0.09 b$ \\
\hline Water activity (\%) & $0.998 \pm 0.001^{a}$ & $0.997 \pm 0.001^{a}$ & $0.996 \pm 0.001^{a}$ \\
\hline Ascorbic acid (mg $100 \mathrm{~g}^{-1}$ ) & $7.34 \pm 0.18^{a}$ & $5.88 \pm 0.22^{b}$ & $2.19 \pm 0.27^{c}$ \\
\hline Proteins $(\%)$ & $1.62 \pm 0.09 b$ & $1.96 \pm 0.12^{a}$ & $1.83 \pm 0.09 a b$ \\
\hline Lipids (\%) & $10.70 \pm 0.11^{a}$ & $9.81 \pm 0.11^{b}$ & $10.81 \pm 0.18^{a}$ \\
\hline Total sugars (\%) & $1.72 \pm 0.00^{\circ}$ & $2.95 \pm 0.00^{b}$ & $3.57 \pm 0.08^{a}$ \\
\hline Reducing sugars (\%) & $0.90 \pm 0.00^{\circ}$ & $1.80 \pm 0.00^{b}$ & $1.87 \pm 0.01^{a}$ \\
\hline Non-reducing sugars (\%) & $0.78 \pm 0.00^{c}$ & $1.09 \pm 0.00^{b}$ & $1.62 \pm 0.08^{a}$ \\
\hline
\end{tabular}

the presence of organic acids and the fruit's ripeness.

Unlike the results obtained in this work, the analysis of the physicochemical parameters of the pequi pulp in natura carried out by Paz et al. (2014) resulted in mean values of $7.00 \pm 0.01$ for $\mathrm{pH}, 15.2 \pm 1.06$ of soluble solids and $0.7 \pm 0.01 \%$ of total titratable acidity. Nascimento \& Cocozza (2015), when studying the physico-chemical characterization of pequi fruits from the Western region of Bahia, observed the following average values for $\mathrm{pH}$, soluble solids, total titratable acidity and SS/ATT ratio, respectively: $5.32,11.95{ }^{\circ}$ Brix, $1.76 \%$ and 11.53 . On the other hand, Souza et al. (2017), when analyzing the physical parameters of fresh cheese flavored with $20 \%$ pequi pulp, obtained $\mathrm{pH}$ values of $6.72 \pm 0.01$ and $0.68 \pm$ 0.00 of acidity (g $100 \mathrm{~g}$ ). The divergences observed in the evaluated parameters can be justified by the addition of whole milk, in different concentrations, to the pequi pulp.

The ash content $(0.48 \pm 0.00)$ was higher in the formulation PL3, which has a higher concentration of whole milk. In the formulation PL1, which has a higher content of pequi pulp, the ash content was $0.23 \pm 0.00$, corroborating the result shown by Magalhães et al. (2018) $(0.25 \pm 0.01)$. Higher values were obtained by Souza ef al. (2017) (2.67 \pm 0.17 ) and Carvalho et al. (2017) (1.65 \pm 1.26); however, in both cases, higher concentrations of milk were used in the analyzed products.

As for the water content, the formulations analyzed did not show a defined behavior, although a statistical difference was observed between the formulations. The average value of water content was high in the three formulations, making them quite perishable. In addition, the values were higher than those observed by Souza et al. (2017) (64.31 \pm 0.16$)$ and Carvalho et al. (2017) (33.7 \pm 0.07 ) for the water content of fresh cheese with $20 \%$ pequi pulp and dulce de leche with $3 \%$ pequi pulp, respectively.

As for water activity, approximate values were observed in the three formulations, compatible for most fruit pulps (> 0.98), showing a tendency in reducing water to the extent that there was an increase in the concentration of milk in the formulations. The highest mean value was found in the formulation with the highest content of pequi pulp (PL1) 0.998 (Table 1). A similar result was mentioned by Sousa (2016), when analyzing the pequi pulp acquired in Chapada do Araripe, in the south of the State of Ceará.

Regarding ascorbic acid, the values were lower than those described in the Brazilian Food Composition Table - TACO (2011) for pequi pulp (8.3 mg $\left.100 \mathrm{~g}^{-1}\right)$. When analyzing the physical-chemical characteristics of pequi in natura in the city of Japonvar - MG, Alves (2014) found

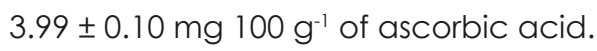

It is worth mentioning that a significant reduction in the levels of ascorbic acid was observed as there was an increase in the addition of whole milk to the formulations (Table 1), which may be related to the fact that milk is a poor source of this vitamin; therefore, the increase in milk concentrations may justify the reduction of ascorbic acid in the formulations analyzed. Another possible justification stems from losses during pulp processing and storage time.

Table 1 shows that there was a statistical difference in protein content when comparing the formulations PL 1 (1.62 \pm 0.09$)$ and PL2 (1.96 \pm 0.12$)$, however, there was no statistical difference with respect to PL3 (1.83 \pm 0.09$)$.

As for lipids, there was a reduction in the mean values of this nutrient when adding $30 \%$ whole milk to the pequi pulp (PL2); however, there was no statistical difference between formulations with 10\% (PL1) and 50\% (PL3) of milk, respectively (Table 1). 
Alves et al. (2014), when analyzing the pequi pulp from the state of Tocantins, found higher mean values

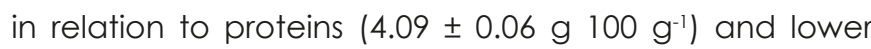

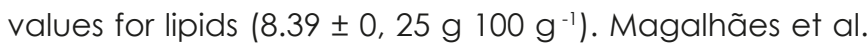
(2018) observed approximate values for proteins (1.35 \pm

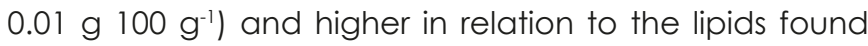

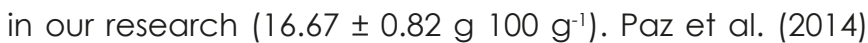
described higher mean values for proteins $(2.4 \pm 0.10 \%)$ and lipids (31.5 $\pm 0.52 \%)$. Machado et al. (2015) found

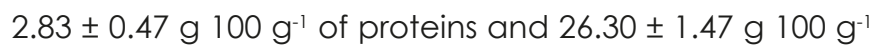
of lipids in the analyzed pequi pulp.

Regarding sugars (total, reducing and nonreducing), there was an increase as the concentration of whole milk increased, obtaining higher values in PL3. There was a statistical difference between the three formulations.

Sousa (2016), when characterizing the pequi pulp, found levels for total (AT), reducing (AR) and nonreducing (ANR) sugars equal to $0.83 \%$ glucose, $0.62 \%$ glucose and $0.20 \%$ sucrose, respectively. While Sousa (2013) obtained $1.25 \%$ glucose (AT), $0.69 \%$ glucose (AR) and $0.53 \%$ (ANR) sucrose for pequi pulp.

Table 2 shows the average values of the physical color analysis. The brightness parameter (L) ranges from 0 (black) to 100 (white). The closer to 100, the clearer the sample appears. The luminosity indices of the samples tend to white with values varying from 62.03 to 64.34 , where the PL3 formulation showed greater luminosity, indicating that is the clearest sample. However, it is noted that there was a statistical difference between the three formulations. The coordinate $a^{*}$ was positive in the three formulations, indicating that the samples have red intensity and there was no significant difference between formulations PL1 and PL2 (Table 2). Regarding the coordinate $b^{*}$, the three formulations were positive indicating that they have yellow intensity and there was a significant difference between them. However, it is observed that PL2 showed a higher intensity of yellow $(29,38)$. The PL2 formulation stood out among the others in terms of physical color analysis, as it presented the highest values of $L^{*}, a^{*}$ and $b^{*}$ due to the higher proportion of pequi pulp.

Sousa et al. (2012), when evaluating the parameters of pequi pulp color, obtained the following results: $L^{*}=69.82, a^{*}=3.02$ and $b^{*}=33.49$. While Alves (2014) found the following values for $L^{*}=53.95 \pm 3.94, a^{*}=$ $22.50 \pm 3.54, b^{*}=66.60 \pm 5.63$.

For the chromaticity parameter, PL3 differed statistically from the others due to the proportions of pulp and milk used.

The PL3 formulation presented a greater tonality angle, differing statistically from the other formulations. This fact is due to the greater amount of milk.

Table 2. Average values of instrumental color parameters ( $L^{*}, a^{*}$ and $b^{*}$ ) of pequi pulp formulations with different concentrations of whole milk.

\begin{tabular}{|c|c|c|c|}
\hline \multirow{2}{*}{ Parameters analyzed } & \multicolumn{3}{|c|}{ Formulations } \\
\hline & PL1 & PL2 & PL3 \\
\hline Brightness (L*) & $63.55 \pm 0.27^{b}$ & $62.03 \pm 0.12^{c}$ & $64.34 \pm 0.32^{a}$ \\
\hline Intensity of red (+ $\left.a^{*}\right)$ & $4.88 \pm 0.08^{a}$ & $4.47 \pm 0.32^{a}$ & $3.41 \pm 0.27^{b}$ \\
\hline Yellow intensity (+ b*) & $28.64 \pm 0.19^{b}$ & $29.38 \pm 0.33^{a}$ & $26.21 \pm 0.41^{c}$ \\
\hline Chroma (c*) & $29.06 \pm 0.18^{a}$ & $29.72 \pm 0.38^{a}$ & $26.44 \pm 0.37^{b}$ \\
\hline Tint angle (h*) & $80.33 \pm 0.19^{c}$ & $81.35 \pm 0.52^{b}$ & $82.58 \pm 0.69^{a}$ \\
\hline
\end{tabular}

\section{Conclusions}

The mixture of milk with the pequi pulp changed the physical and physical-chemical characteristics of the pulp. The formulation PL3 presented the more interesting properties compared to the others formulations tested, since it had lower total titratable acidity, water activity, red intensity, yellow intensity and chromaticity, however, higher content of total soluble solids, ratio SST/ATT, ash, lipids, sugars (total, reducing and non-reducing), brightness and tint angle.

The variability in the results with respect to the evaluated characteristics is directly related to the influence of the variation in the content of whole milk used in the formulations; as well as due to particular characteristics of the fruit, its type and the place of cultivation, as well other conditions, such as the time, processing and/or storage conditions.

The addition of whole milk to the pequi pulp is an interesting alternative to add nutritional value by increasing the content of proteins of high biological value, which can be a promising product in the market.

\section{References}

Alves, A.M., Fernandes, D.C., Sousa, A.G.O., Naves, R.V., Naves, M.M.V. 2014. Características físicas e nutricionais de pequis oriundos dos estados de Tocantins, Goiás e Minas Gerais. Brazilian Journal of Food Technology 17: 198-203.

Alves, A.I. 2014. Obtenção de extrato de carotenoide 
de polpa de pequi (Caryocar brasiliense Camb.) encapsulado pelo método de secagem por atomização. 78f. (Dissertação de mestrado) - Universidade Federal de Viçosa, Viçosa, Brazil.

AOAC, Association Of Official Analytical Chemistry. 2009. Official methods of analysis of the Association of Official Analytical Chemistry. Association of Official Analytical Chemists, Washington, USA. 1115 p.

Batista, J.S., Silva, A.E., Rodrigues, C.M.F., Costa, K.M.F.M., Oliveira, A.F., Paiva, E.S., Nunes, F.V.A., Olinda, R.G. 2010. Avaliação da atividade cicatrizante do óleo de pequi (Caryocar Coriaceum wittm) em feridas cutâneas produzidas experimentalmente em ratos. Arquivos do Instituto Biológico 77: 441- 447.

Benassi, M.T., Antunes, A.J.A. 1998. Comparison of metaphosphoric and oxalic acids as extratroctant solution for the determination of vitamin $C$ in selected vegetables. Arquivos de Biologia e Tecnologia 13: 507-573.

Bligh, E.G., Dyer, W.J. 1959. A rapid method of total lipid extraction and purification. Canadian Journal of Biochemistry and Physiology 37: 911-917.

Brasil. Instituto Adolfo Lutz. Normas analíticas do Instituto Adolfo Lutz. 2008. Métodos físico-químicos para análise de alimentos. IMESP, São Paulo, Brazil.

Carvalho, B.S., Silva, M.A.P., Souza, D.G., Moura, L.C., Vieira, N.F., Plácido, G.R., Caliari, M. 2017. Perfil sensorial e físico-químico do doce de leite com pequi (Caryocar brasiliense Camb). Global Science Technology 10: 128135.

Leão, D.P., Franca, A.S., Oliveira, L.S., Bastos, R., Coimbra, M.A.2017.Physicochemicalcharacterization, antioxidacnt capacity, total phenolic and proanthocyanidin content of flours prepared from pequi (Caryocar brasilense Camb.) fruit by-products. Food Chemistry 225: 146-153.

Lima, C.M.G., Santos, J.J., Miranda, R.F., Viana, R.B.B, Santos, M.S., Barbosa, E.A. 2017. Aceitabilidade de geleia de pimenta dedo-de-moça com pectina da casca do pequi. The Journal of Engineering and Exact Sciences 3: 786-791.

Machado, M.T.C., Mello, B.C.B.S., Hubinger, M.D. 2015. Evaluation of pequi (Caryocar Brasiliense Camb.) aqueous extract quality processed by membranes. Food and Bioproducts Processing 95: 304-312.

Magalhães, F.S., Cardoso, V.L., Reis, M.H.M. 2018. Sequential process with bioadsorbents and microfiltration for clarification of pequi (Caryocar brasiliense Camb.) fruit extract. Food and Bioproducts Processing 108: 105116.

Maia, J.G.S., Andrade, E.H.A., Silva, M.H.L. 2008. Aroma volatiles of pequi fruit (caryocar brasiliense camb.). Jounal Food Compos 21: 574-576.

Nascimento, R.S.M., Cocozza, F.D.M. 2015. Physicochemical characterization and biometry of fruits of 'pequi' in Western Bahia. Revista Brasileira de Engenharia
Agrícola e Ambiental 19: 791-796.

Oliveira, W.L., Scariot, A. Boas práticas de manejo para o extrativismo sustentável do pequi. Embrapa Recursos Genéticos e biotecnologia, Brasília, Brazil. 84 p.

Paz, J.G., Pacheco, P., Silva, C.O., Pascoal, G.B. 2014. Análise da composição nutricional e de parâmetros físico-químicos do pequi (Caryocar Brasiliense Camb) in natura. Linkania 1: 73-159.

Pinto, L.C.L., Morais, L.M.O., Guimarães, A.Q., Almada, E.D., Barbosa, P.M., Drumond, M.A. 2016. Traditional knowledge and uses of the Caryocar brasiliense Cambess. (Pequi) by "quilombolas" of Minas Gerais, Brazil: subsidies for sustainable management. Brazilian Journal of Biology 76: $511-519$.

Prance, G.T., Silva, M.F. 2006. Flora da reserva Ducke, Amazonas, Brasil. Caryocaraceae. Rodriguésia 57: 155157.

Ribeiro, D.M., Fernandes, D.C., Alves, A.M., Naves, M.M.V. 2014. Carotenoids are related to the colour and lipid content of the pequi (Caryocar brasiliense Camb.) pulp from the Brazilian Savanna. Food Science and Technology 34: $507-512$

Santos, T.A.S.S., Bueno, C.P., Lima, C.S., Rodrigues, M.R., Moraes, D.P. 2016. Elaboração e avaliação sensorial de iogurtes integrais batidos sabor frutos do Brasil. In: III Congresso de Ensino, Pesquisa e Extensão da UEG. Inovação: Inclusão Social e Direitos, 3. Petrópolis, Goiás, 2016.

Saraiva, R.A., Araruna, M.K., Oliveira, R.C., Menezes, K.D., Leite, G.O., KerntopF, M.R., Costa, J.G., Rocha, J.B., Tomé, A.R., Campos, A.R., Menezes, I.R. 2010. Topical anti-inflammatory effect of Caryocar coriaceum Wittm. (Caryocaraceae) fruit pulp fixed oil on mice ear edema induced by diferente irritant agents. Journal Ethnopharmacol 136: $504-510$.

Silva, F.A.S., Azevedo, C.A.V. 2002. Versão do programa computacional Assistat para o sistema operacional Windows. Revista Brasileira de Produtos Agroindustriais 4: 71-78.

Sousa, F.C., Silva, L.M.M., Sousa, E.P., Lima, A.V.O., Figueiredo, R.M.F. 2012. Parâmetros físicos e físico-químicos da polpa de pequi. Revista Verde de Agroecologia e Desenvolvimento Sustentável 6: 12 - 15.

Sousa, E.P. 2013. Propriedades físicas da polpa de pequi. 108f. (Dissertação) - Universidade Federal de Campina Grande, Campina Grande, Brazil.

Sousa, E.P. 2016. Secagem convectiva da polpa do pequi para elaboração de condimento. 171f. (Tese) Universidade Federal de Campina Grande, Campina Grande, Brazil.

Souza, D.G., Silva, M.A.P., Moura, L.C., Dias, L.G., Plácido, G.R., Caliari, M., Oliveira, K.B., Célia, J.A. 2017. Parâmetros físico químicos e sensoriais de queijos saborizados com pequi (Caryocar Brasiliense Camb.). Global Science 
Technology 10: 105-111.

TACO. Tabela brasileira de composição de alimentos.

$2011 . \quad$ http://www.unicamp.br/nepa/taco/tabela.

php?ativo=tabela < Acesso em 20 Jan. 2020>

Conflict of Interest Statement: The authors declare that the research was conducted in the absence of any commercial or financial relationships that could be construed as a potential conflict of interest.

All the contents of this journal, except where otherwise noted, is licensed under a Creative Commons Attribution License attribuition-type BY. 